OPEN ACCESS

Edited by:

Qiaoyun Huang,

Huazhong Agricultural University,

China

Reviewed by:

Meng Zhang,

Nanyang Technological University,

Singapore

Wei $L i$,

East China University of Science and Technology, China

${ }^{*}$ Correspondence:

Chongde Wu

cdwu@scu.edu.cn

Specialty section:

This article was submitted to

Microbiotechnology,

a section of the journal

Frontiers in Microbiology

Received: 14 November 2019

Accepted: 17 February 2020

Published: 06 March 2020

Citation:

Li D, Liang X and Wu C (2020)

Characteristics of Nitrogen Removal and Extracellular Polymeric Substances of a Novel Salt-Tolerant Denitrifying Bacterium, Pseudomonas sp. DN-23. Front. Microbiol. 11:335.

doi: 10.3389/fmicb.2020.00335

\section{Characteristics of Nitrogen Removal and Extracellular Polymeric Substances of a Novel Salt-Tolerant Denitrifying Bacterium, Pseudomonas sp. DN-23}

\author{
Dan $\mathrm{Li}^{1,2}$, Xihong Liang ${ }^{1,2}$ and Chongde $\mathrm{Wu}^{1,2 *}$ \\ ${ }^{1}$ College of Biomass Science and Engineering, Sichuan University, Chengdu, China, ${ }^{2}$ Key Laboratory of Leather Chemistry \\ and Engineering, Ministry of Education, Sichuan University, Chengdu, China
}

Extracellular polymeric substances (EPS) influence the auto-aggregation performance of cells and play an important role in nitrogen removal during wastewater treatment. In this study, a salt-tolerant aerobic denitrifying bacterium was isolated from tannery wastewater and identified as Pseudomonas sp. DN-23. The strain exhibited significant growth and denitrifying performance, with $\mathrm{NaCl}$ contents ranging from 0 to $50 \mathrm{~g} / \mathrm{L}$, and high antioxidative enzyme activity, especially that of catalase (CAT), was detected under salt stress. Even greater auto-aggregation ability was observed with elevated $\mathrm{NaCl}$ content. Extinction-emission matrix (EEM) and Fourier-transform infrared (FTIR) spectrum analyses showed that the main components of EPS were proteins and polysaccharides. The polysaccharide content was almost unaffected by $\mathrm{NaCl}$ stress, while the protein content increased with $\mathrm{NaCl}$ stress, and the proteins may play a more important role in auto-aggregation. Analysis of the contents of each protein's secondary structure suggested that $\beta$-Sheets increased with increasing $\mathrm{NaCl}$ content, which may be related to the increase of auto-aggregation ability in response to $\mathrm{NaCl}$ stress. Therefore, $\mathrm{NaCl}$ stress increased the auto-aggregation performance by altering the compositions of EPS and the distribution of protein secondary structures. This study provided further insight into the denitrifying performance, and the relationship between aggregation ability and EPS characteristics under $\mathrm{NaCl}$ stress.

Keywords: salt-tolerant denitrifying bacterium, $\mathrm{NaCl}$ stress, auto-aggregation performance, extracellular polymeric substances, protein secondary structures

\section{INTRODUCTION}

Ammonium waste streams are massively discharged from landfills along with fish-canning, dyeing, tannery, and chemical plants. Due to the presence of large amounts of salts as chlorides $(0-$ $100 \mathrm{~g} / \mathrm{L}$ ), such streams significantly affect the nitrifying-denitrifying performance of various nitrogen removal processes (Wang et al., 2014; Raman and Kanmani, 2016). Numerous studies have reported that low salinity inhibits the enzyme activities of denitrifying bacteria, whereas high salinity causes cell plasmolysis and eventually leads to bacteria death. Moreover, when the cells are 
cultured in a high-salt environment, the pathways of nitrogen metabolism would be altered, and the expression of denitrifying genes would be diminished ( $\mathrm{Yu}$ et al., 2015). In addition to its influence on cells, salt also affects the density and amount of dissolved oxygen in wastewater. For example, the salinity would also change the physical and biochemical properties of activated sludge such as structure, hydrophobicity, setting, flocculation, etc. (Bassin et al., 2012).

In recent years, many heterotrophic nitrifying-denitrifying bacteria have been isolated and introduced into wastewater biological treatment processes, such as Vibrio diabolicus SF16 (Duan et al., 2015), Diaphorobacter sp. PD-7 (Ge et al., 2015), and Pseudomonas stutzeri PCN-1 (Zheng et al., 2014). Moreover, many researchers have utilized autochthonoushalophilic bacteria to treat saline wastewater (Campo et al., 2018; Corsino et al., 2018). Among these, two marine bacterial strains, Bacillus sp. KGN1 and Vibrio sp. KGP1, were used in the form of aerobic granule sludge to treat saline wastewater in a labscale sequencing batch reactor system (SBR) (Eom et al., 2018). The results showed that the SBR containing $B$. sp. HGN1 and $V$. sp. KGP1 was more efficient at removing COD, nitrogen, and phosphate. However, little was known about the effect of $\mathrm{NaCl}$ stress on the denitrification characteristics of aerobic salt-tolerant denitrifying bacteria.

In addition to the denitrifying characteristics of salt-tolerant denitrifying bacteria, the auto-aggregation performance changes caused by extracellular polymeric substances (EPS) deserve more attention. EPS are made of various compounds such as proteins, polysaccharides, DNA, and humic acids, and the functional groups of EPS play an important role in microbial aggregation, sludge setting, and biofilm formation (Chen et al., 2013 b). In addition, it has been reported that EPS contributes to the adsorption and adhesion of metal ions and organic pollutants because of the hydrophobic and hydrophilic regions in their structures (Jia et al., 2016). Microorganisms growing in unfavorable conditions produce additional EPS to protect themselves by balancing osmotic pressure (Tourney et al., 2009; Corsino et al., 2015). Nowadays, many researchers have reported the importance of EPS in forming granules and biofilms. Campo et al. (2018) showed that microorganisms metabolize EPS as an additional carbon source when facing insufficient energy, and a particular EPS metabolism contributed to aerobic granulation in saline wastewater. It was reported that EPS promoted the aggregation of suspended sludge cells by determining the compositions and physicochemical characteristics of EPS, which was ascribed to the hydrophilic cell surface and reduced zeta potentials (Zhang et al., 2014). In addition, many researchers have explored the relationship between the auto-aggregation abilities and EPS characteristics of culturable microorganisms from special environments. Acinetobacter calcoaceticus, used for phenol degradation, exhibited excellent auto-aggregation ability because of the secreted EPS, which had the potential to form single cultured granules (Adav and Lee, 2008). Gupta and Thakur (Gupta and Thakur, 2016) isolated a thermotolerant Bacillus sp. ISTVK1 from heat-shocked sewage sludge, and this strain produced plenty of EPS during the removal of wastewater contaminants. Moreover, Li et al. (2018) found that the EPS secreted by Klebsiella sp. J1 was able to immobilize hexavalent uranium $[\mathrm{U}(\mathrm{VI})]$ and mediate partial $[\mathrm{U}(\mathrm{VI})]$ reduction in the presence of $\mathrm{H}_{2}$. However, few reports have focused on the autoaggregation performance and EPS characteristics of salt-tolerant denitrifying bacteria.

The purpose of the present study was to explore the effects of $\mathrm{NaCl}$ stress on the growth and denitrifying characteristics of a salt-tolerant aerobic denitrifying bacterium. Special attention was given to the auto-aggregation performance and EPS characterizations of the bacterium in response to $\mathrm{NaCl}$ stress.

\section{MATERIALS AND METHODS}

\section{Media for Bacterial Enrichment and Cultivation}

The compositions of enrichment medium (EM) and basic medium (BM) were as follows (per liter): $0.72 \mathrm{~g} \mathrm{KNO}_{3}, 5 \mathrm{~g}$ sodium acetate, $1 \mathrm{~g} \mathrm{~K}_{2} \mathrm{HPO}_{4}, 1 \mathrm{~g} \mathrm{KH}_{2} \mathrm{HPO}_{4}, 0.5 \mathrm{~g} \mathrm{MgSO}_{4}$, $30 \mathrm{~g} \mathrm{NaCl}, 1 \mathrm{~mL}$ trace element solution, $\mathrm{pH}$ 7.0. A modified Bromothymol blue (BTB) medium used for the isolation of salttolerant aerobic denitrifying bacteria contained the following components (per liter): $0.72 \mathrm{~g} \mathrm{KNO}_{3}, 5 \mathrm{~g}$ sodium acetate, $1 \mathrm{~g}$ $\mathrm{K}_{2} \mathrm{HPO}_{4}, 1 \mathrm{~g} \mathrm{KH} \mathrm{HPO}_{4}, 0.5 \mathrm{~g} \mathrm{MgSO}_{4}, 30 \mathrm{~g} \mathrm{NaCl}, 1 \mathrm{~mL}$ of trace element solution, $20 \mathrm{~g}$ agar, $1 \mathrm{~mL}$ BTB solution (1\% in ethanol), $\mathrm{pH}$ 7.0. The denitrification medium (DM) used for studying the denitrifying characteristics of salt-tolerant bacteria was as follows (per liter): $0.72 \mathrm{~g} \mathrm{KNO}_{3}, 8.2 \mathrm{~g}$ sodium acetate, $1 \mathrm{~g} \mathrm{~K}_{2} \mathrm{HPO}_{4}, 1 \mathrm{~g}$ $\mathrm{KH}_{2} \mathrm{HPO}_{4}, 0.5 \mathrm{~g} \mathrm{MgSO}_{4}, 1 \mathrm{~mL}$ of trace element solution, $\mathrm{pH}$ 8.0. $\mathrm{NaCl}$ was added as needed $(0,30$, or $50 \mathrm{~g} / \mathrm{L})$. The composition of the trace element solution was as follows (per liter): $50 \mathrm{~g}$ EDTA, $2.2 \mathrm{~g} \mathrm{ZnSO}_{4} \cdot 7 \mathrm{H}_{2} \mathrm{O}, 5.5 \mathrm{~g} \mathrm{CaCl}_{2} \cdot \mathrm{H}_{2} \mathrm{O}, 2.06 \mathrm{~g} \mathrm{MnCl}_{2}, 5 \mathrm{~g}$ $\mathrm{FeSO}_{4} \cdot 7 \mathrm{H}_{2} \mathrm{O}, 1.1 \mathrm{~g}\left(\mathrm{NH}_{4}\right)_{6} \mathrm{Mo}_{7} \mathrm{O}_{24} \cdot 4 \mathrm{H}_{2} \mathrm{O}, 1.57 \mathrm{~g} \mathrm{CuSO}_{4} \cdot 5 \mathrm{H}_{2} \mathrm{O}$, $1.61 \mathrm{~g} \mathrm{CoCl}_{2} \cdot 6 \mathrm{H}_{2} \mathrm{O}$, pH 7.0 .

\section{Isolation and Identification of a Salt-Tolerant Aerobic Denitrifier}

$10 \mathrm{~mL}$ of sludge sample, collected from a sequencing batch reactor in Ruixing Leather Industry Co., Ltd., Zhejiang, China, was transferred to a $250 \mathrm{~mL}$ Erlenmeyer flask containing $90 \mathrm{~mL}$ of sterilized enrichment medium. After incubating for $48 \mathrm{~h}$ $\left(150 \mathrm{rpm}, 30^{\circ} \mathrm{C}\right)$, the homogeneous bacterial suspensions $(10 \mathrm{~mL})$ were transferred to another $90 \mathrm{~mL}$ of fresh EM and incubated under the same conditions as above. This procedure was repeated three times. After diluting them by gradient, the bacterial suspensions were spread on the BTB medium plates. The plates were incubated at $30^{\circ} \mathrm{C}$ for a few days until visible blue colonies were formed. Then, separate colonies were purified via repeated streaking on BTB medium plates. Pure isolates were obtained and their denitrifying ability was tested individually in BM. The isolate with the greatest denitrifying rate was suspended in $30 \%$ glycerol solution at $-80^{\circ} \mathrm{C}$ for long-term storage.

To identify the salt-tolerant denitrifying bacterium, total bacterial DNA was extracted using the EZ-10 Column Genomic (Sangon, Shanghai, China). The 16S rDNA gene 
was amplified by PCR using the universal bacterial primers $5^{\prime}$ AGAGTTTGATCCTGGCTAG and 5'-TACGGTTACCTTGTT ACGACTT, and sequenced by Sangon Biotech Co., Ltd. The sequence was analyzed and compared in the Genbank using BLAST $^{1}$. Finally, a neighbor-joining tree was constructed in MEGA7.

\section{Optimization of the Cultivation Conditions for Aerobic Denitrification}

The growth and aerobic denitrifying characteristics of the salt-tolerant bacterium were conducted under varied culture conditions, including carbon source, $\mathrm{C} / \mathrm{N}$ ratio, $\mathrm{pH}$, and temperature. In the carbon source experiments, glucose, sodium pyruvate, sodium citrate, and sodium succinate were used in the $\mathrm{BM}$ instead of sodium acetate. As for the $\mathrm{C} / \mathrm{N}$ ratio, different $\mathrm{C} / \mathrm{N}$ ratios $(3,6,12,18$, and 24$)$ were obtained by adjusting the sodium acetate content. To determine the effects of $\mathrm{pH}$ and temperature on the denitrifying capabilities of the isolate, the initial $\mathrm{pH}$ was adjusted to $6,7,8,9,10$, or 11 , and the temperature was set at $10,20,30$, or $37^{\circ} \mathrm{C}$. All of the above experiments were conducted with $1 \%(\mathrm{v} / \mathrm{v})$ inoculation size in $100 \mathrm{~mL}$ of sterile medium, in triplicate. The cells were cultivated for $48 \mathrm{~h}\left(30^{\circ} \mathrm{C}, 150 \mathrm{rpm}\right)$ in shake flasks, and samples were harvested to determine the $\mathrm{OD}_{600}$ and the concentration of nitrate.

\section{Effects of $\mathrm{NaCl}$ Stress on the Aerobic Denitrification of the Isolate}

To evaluate the effects of $\mathrm{NaCl}$ stress on the aerobic denitrification characteristics, $1 \mathrm{~mL}$ of the pre-cultured isolate was inoculated into $100 \mathrm{~mL}$ of sterile $\mathrm{DM}$ containing different concentrations of $\mathrm{NaCl}(0,30$, or $50 \mathrm{~g} / \mathrm{L})$. The isolate in the Erlenmeyer flask was aerobically cultured in a shaker $(150 \mathrm{rpm})$ at $30^{\circ} \mathrm{C}$. The samples were harvested from the DM periodically by centrifugation $(10000 \mathrm{rpm}, 5 \mathrm{~min})$. Then, the contents of $\mathrm{TN}, \mathrm{NO}_{3}{ }^{-}-\mathrm{N}, \mathrm{NO}_{2}{ }^{-}-\mathrm{N}$, and cell optical density $\left(\mathrm{OD}_{600}\right)$ were measured. Each treatment was conducted in triplicate.

\section{Determination of Antioxidant Enzyme Activities}

The strain was cultivated to logarithmic metaphase and the cells were collected by centrifugation $\left(10000 \mathrm{rpm}, 4^{\circ} \mathrm{C}\right)$ for $5 \mathrm{~min}$, washed two times with ultrapure water, and then resuspended in ultrapure water. The cells were lysed by ultrasonication on ice $(20 \mathrm{kHz}, 15 \mathrm{~min})$ and then centrifuged (10000 rpm, $10 \mathrm{~min}$, $4^{\circ} \mathrm{C}$ ) to obtain cell extracts as a crude enzyme. Assay Kits (Jiancheng, Nanjing, China) were used to determine the activities of superoxide dismutase (SOD), catalase (CAT), and peroxidase (POD). Protein concentration was determined by using the Bradford Protein Assay Kit (Biyuntian, Haimen, China) (Bin et al., 2008). Enzyme specific activity (U/mg) was defined as the amount of enzyme that transformed $1 \mu \mathrm{mol}$ substrate per minute by the amount of milligram protein.

${ }^{1}$ https://www.ncbi.nlm.nih.gov/

\section{Flocculating Test and the Auto-Aggregation Ability of the Isolate}

The flocculating rate of the isolate cultivated in media with different $\mathrm{NaCl}$ concentrations $(0,30$, and $50 \mathrm{~g} / \mathrm{L})$ was determined according to the method reported by Huang et al. (2005). In general, $0.4 \mathrm{~g}$ kaolin, $5 \mathrm{~mL} 1 \% \mathrm{CaCl}_{2}$, and $93 \mathrm{~mL}$ ultrapure water were put into a $200-\mathrm{mL}$ beaker. Then, $2 \mathrm{~mL}$ of fermentation broth was added to the beaker. The liquid was agitated for 2 min with a magnetic stirrer, transferred to a $100-\mathrm{mL}$ cylinder, and then remained static for $5 \mathrm{~min}$. The absorbance of the supernatant and control solution (ultrapure water was used instead of fermentation broth) was measured at $550 \mathrm{~nm}$ as $\mathrm{OD}_{550}$

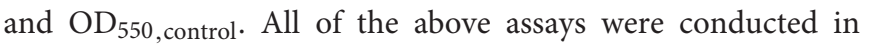
triplicate. The flocculation rate was defined and calculated by the following Eq. 1 (Zhang et al., 2014):

$$
\begin{aligned}
\text { Flocculating efficiency }(\%)= & \left(\mathrm{OD}_{550, \text { control }}-\mathrm{OD}_{550}\right) \\
& / \mathrm{OD}_{550, \text { control }} \times 100
\end{aligned}
$$

To investigate the auto-aggregation ability, cells cultivated to logarithmic metaphase in $\mathrm{DM}$ containing $\mathrm{NaCl}(0,30$, or $50 \mathrm{~g} / \mathrm{L})$ were collected by centrifugation $\left(10000 \mathrm{~g}, 4^{\circ} \mathrm{C}\right)$ for $5 \mathrm{~min}$, washed three times by ultrapure water, and resuspended in the same water. The auto-aggregation rate of cells was determined according to the method reported by Zhang et al. (2014). The initial $\mathrm{OD}_{600}$ of the cell suspension was adjusted to 0.6 , and $5-\mathrm{mL}$ suspensions were transferred into a test tube. Subsequently, the test tube was left standing for $1,2,3,4$, and $5 \mathrm{~h}$, and the $\mathrm{OD}$ corresponding to cells at the upper part of the cuvette was measured at $600 \mathrm{~nm}\left(\mathrm{~A}_{t}\right)(t=1,2,3,4,5 \mathrm{~h})$. The autoaggregation rate (At) of microbial cells was calculated by Eq. (2) (Sheng and $\mathrm{Yu}, 2006$ ).

Auto - aggregation rate $(\%)=\left(1-\mathrm{A}_{\mathrm{t}} / \mathrm{A}_{0}\right) \times 100 \%$

Here $A_{0}$ is the $\mathrm{OD}_{600}$ at time 0 , namely initial $\mathrm{OD}_{600}$.

\section{Zeta Potential}

The zeta potentials of cells in response to $\mathrm{NaCl}$ stress $(0$, 30 , or $50 \mathrm{~g} / \mathrm{L}$ ) were determined using Zetasizer Nano ZS90 (Malvern Instruments, United Kingdom) according to previous methods (Bernstein et al., 2011). Briefly, the $\mathrm{OD}_{546}$ of the collected cells in ultrapure water was adjusted to 0.1 and the zeta potentials were measured by bacterial electrophoretic mobility (Bernstein et al., 2011).

\section{Extracellular Polymeric Substances (EPS) Extraction}

The EPS was extracted according to a modified cation exchange resin (CER) method developed by Liang et al. (2010) Cells cultivated in the DM with $\mathrm{NaCl}$ concentrations of 0,30 , and $50 \mathrm{~g} / \mathrm{L}$ were collected at logarithmic metaphase. Then, $40 \mathrm{~mL}$ of each cell suspension was harvested by centrifugation 
(5000 rpm, $5 \mathrm{~min}, 4^{\circ} \mathrm{C}$ ), washed three times with ultrapure water, and resuspended to its initial volume with ultrapure water. The $\mathrm{OD}_{600}$ of different samples was adjusted to be the same, and then the suspensions were transferred into 250$\mathrm{mL}$ flasks with CER (70 g/g dry cells) added. The flasks were shaken in a thermostat at $150 \mathrm{rpm}$ for $1 \mathrm{~h}$ at $4^{\circ} \mathrm{C}$ and left standing for $3 \mathrm{~min}$ to settle the CER. Subsequently, the suspension was centrifuged for $15 \mathrm{~min}\left(5000 \mathrm{rpm}, 4^{\circ} \mathrm{C}\right)$, filtered through a $0.45-\mu \mathrm{m}$ filter, and stored at $-20^{\circ} \mathrm{C}$ for further analysis. The dry weight of cells was measured according to Standard Methods. The concentration of polysaccharides was determined by anthrone colorimetry (Raunkjær et al., 1994). The concentration of proteins was determined according to the method described in section "Determination of Antioxidant Enzyme Activities."

\section{Three-Dimensional Extinction-Emission Matrix (3D-EEM) Spectrum of EPS}

The 3D-EEM of EPS was identified using a luminescence spectrophotometer (F-7000 FL, Hitachi, Japan). The EEM spectra of EPS were gathered with subsequent scanning emission (Em) spectra from 250 to $500 \mathrm{~nm}$ by varying the excitation (Ex) wavelength from 200 to $450 \mathrm{~nm}$. Both excitation and emission slits were maintained at $5 \mathrm{~nm}$, and the scanning speed was set at $1200 \mathrm{~nm} \mathrm{~min}{ }^{-1}$ for all measurements. Software Origin 9.1 was employed to process the 3D-EEM data. The EEM spectra were plotted as the elliptical shape of contours, whereby the $X$-axis represented the emission spectra from 250 to $500 \mathrm{~nm}$, while the $Y$-axis represented the excitation spectra from 200 to $450 \mathrm{~nm}$.

\section{Fourier-Transform Infrared (FT-IR) Analysis of the EPS}

The FT-IR spectrum was used to analyze the EPS components. The EPS extracts were freeze-dried in a refrigerator for $48 \mathrm{~h}$ at $-70^{\circ} \mathrm{C}$, and the samples were mixed with $\mathrm{KBr}$ in an agate grinder at a ratio of 1:100. Then, the homogenized powders were molded into a disk. The FT-IR spectra were recorded in the 4500-400 $\mathrm{cm}^{-1}$ region using FT-IR spectrophotometer 510FT (Rayleigh Analytical Instrument Corporation, Beijing). Date derivation was performed with Origin 9.1 software.

\section{The Measure of Protein Secondary Structure in EPS}

Circular dichroism (CD) spectroscopy can be used to analyze the secondary structure of proteins in solution (Perez-Iratxeta and Andrade-Navarro, 2008). The protein concentration of extracted EPS was diluted to $1.0 \mathrm{mg} / \mathrm{L}$. A circular dichroism spectrometer (J715, JASCO, Japan) was used to obtain CD spectra in a $1.00 \mathrm{~cm}$ path-length quartz cuvette. The far-UV CD spectrum was corded at the $0.1-\mathrm{nm}$ interval, and the time constant was $3.0 \mathrm{~s}$. The $\mathrm{CD}$ spectrum was analyzed and calculated by the self-consistent method SELECON3 (Sreerama and Woody, 2000).

\section{Analytical Methods}

The growth of the isolate was measured at $600 \mathrm{~nm}\left(\mathrm{OD}_{600}\right)$ using a Spectrophotometer (UV-1901, Puxi, Beijing). The cell dry weight was obtained by drying at $105^{\circ} \mathrm{C}$. The nitrite was measured by $\mathrm{N}$-(1-naphthalene)-diaminoethane ultraviolet spectroscopy at $540 \mathrm{~nm}$ (Clesceri et al., 2005). The concentration of total nitrogen (TN) was measured by phenol disulfonic acid ultraviolet spectroscopy, and the nitrate concentration was determined by the phenol disulfonic acid method (APHA, 1998).

\section{RESULTS}

\section{Isolation and Identification}

40 purified strains were tested for their denitrifying ability in a high-salt environment $(\mathrm{NaCl} 30 \mathrm{~g} / \mathrm{L})$. One isolate, named DN-23, demonstrated the greatest nitrate removal ability in BM. The nucleotide sequence of the strain DN-23 was submitted to GenBank nucleotide sequence databases. The blast results suggested that the strain DN-23 showed the greatest similarity (99\%) to Pseudomonas balearica DSM. A neighborjoining phylogenetic tree of the isolate was constructed in MEGA 7 based on the nucleotide sequence (Supplementary Figure S1). Based on the result of the 16S rDNA gene sequence, the isolate was named Pseudomonas sp. DN-23, and deposited in the China Center for Type Culture Collection (CCTCC: M2018290).

\section{Denitrification Characteristics of Strain DN-23 Under Various Conditions}

The carbon source, serving as an energy and electron source, has long been considered to be an important factor for the growth and nitrate removal ability of denitrifiers. In the present study, glucose, sodium acetate, sodium pyruvate, sodium citrate, and sodium succinate were used as the sole carbon source in the DM (Figure 1A). Among these five carbon sources, the maximum biomass (0.77) and the greatest denitrification rate $(96.83 \%)$ were observed when using sodium acetate. When cultivated in the other four carbon sources, the strain DN-23 had lower growth and denitrification rates (75.1393.31\%). Thus, sodium acetate was employed in subsequent experiments. The effects of $\mathrm{C} / \mathrm{N}$ on the cell growth and denitrifying rate were explored (Figure 1B). The biomass and nitrate removal efficiency increased with the $\mathrm{C} / \mathrm{N}$ ratio, from $3: 1$ to $12: 1$. The peak of $\mathrm{OD}_{600}$ and denitrification rate were 1.21 and $98.03 \%$, respectively, occurring at $\mathrm{C} / \mathrm{N}$ 12:1. Thus, in the present study, $\mathrm{C} / \mathrm{N} 12: 1$ was used in subsequent experiments.

The cellular growth and denitrification rates at different pHs are shown in Figure 1C. The strain DN-23 had efficient denitrification abilities at initial pHs of 7-10, namely neutral or slightly alkaline environments. The greatest removal rate of $98.59 \%$ and the maximum biomass 1.25 were observed at an initial $\mathrm{pH}$ of 8 . Figure 1D showed the effects of temperature on the biomass and denitrification ability of strain DN-23. The optimal culture temperature was $30^{\circ} \mathrm{C}$, with a maximum $\mathrm{OD}_{600}$ of 1.58 and a maximum denitrification rate of $95.53 \%$. The strain was nearly unable to grow at $10^{\circ} \mathrm{C}$. As the temperature increased 

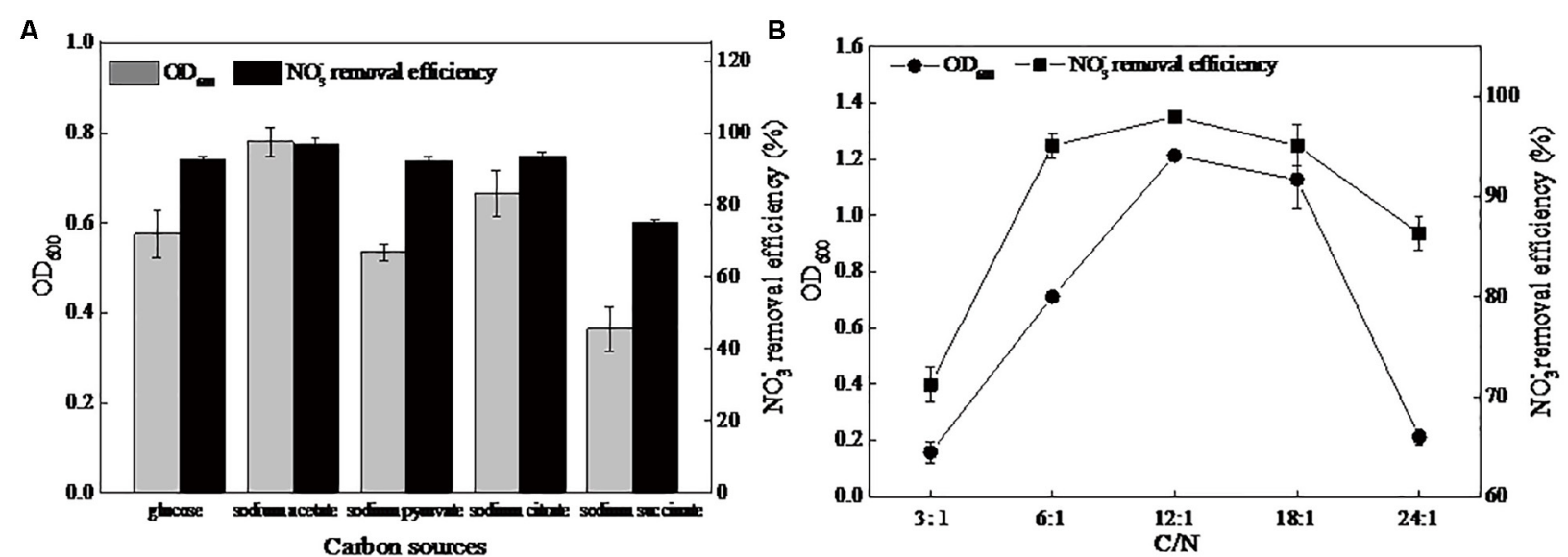

C

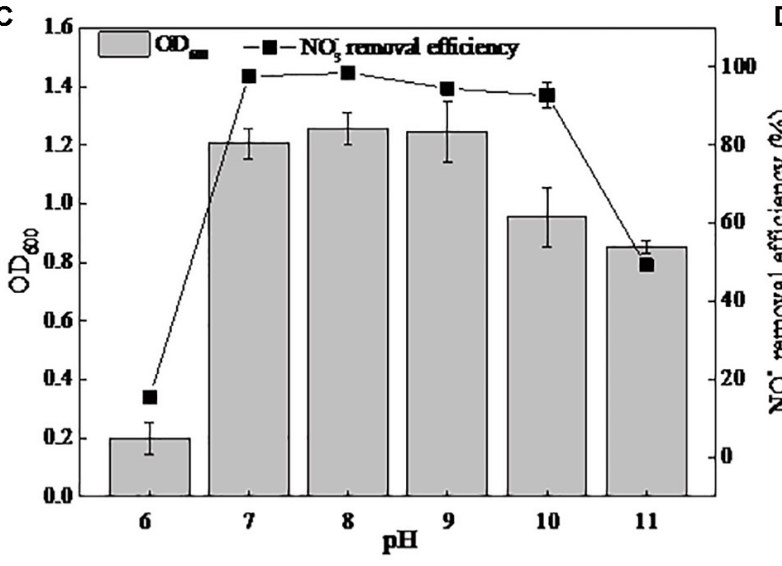

D

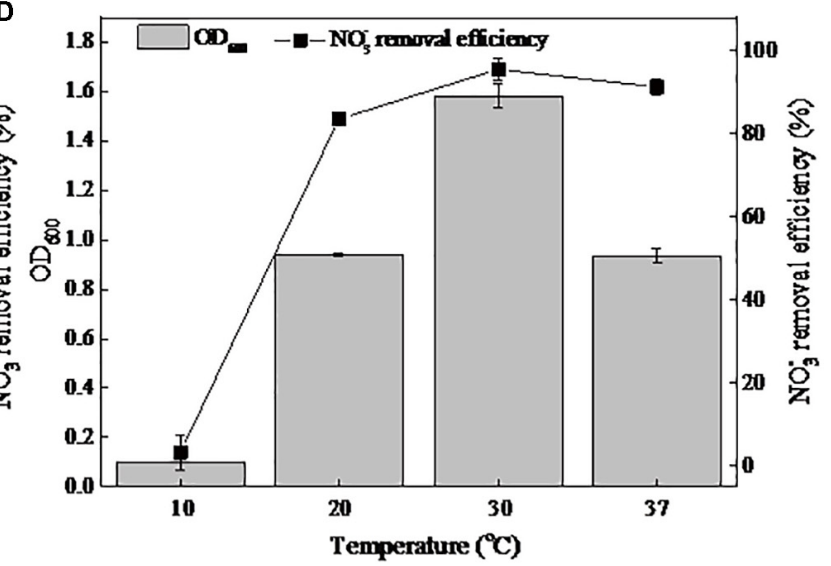

FIGURE 1 | Effects of different factors on the growth and nitrate removal of strain DN-23 in a high-salt environment (30 g/L NaCl). (A): carbon source, (B): C/N, (C): $\mathrm{pH}, \mathbf{( D )}$ : temperature. The biomass and nitrate removal rate were determined after $48 \mathrm{~h}$ of culture. Values are means $\pm \mathrm{SD}$ (error bars) for three replicates.

to $37^{\circ} \mathrm{C}$, the $\mathrm{OD}_{600}$ and denitrification rate reduced to 0.93 and $91.38 \%$, respectively.

\section{Effects of $\mathrm{NaCl}$ on Denitrification Characteristics of DN-23}

The strain DN-23 was cultivated in DM containing different $\mathrm{NaCl}$ concentrations, and the time courses of $\mathrm{OD}_{600}, \mathrm{TN}, \mathrm{NO}_{3}{ }^{-}-\mathrm{N}$, and $\mathrm{NO}_{2}{ }^{-}-\mathrm{N}$ were measured (Figure 2). Figure 2A shows the growth and denitrification characteristics of strain DN-23 in the absence of $\mathrm{NaCl}$. The cell growth increased rapidly from $4 \mathrm{~h}$ and reached a peak of $\mathrm{OD}_{600} 1.48$ at $42 \mathrm{~h}$, with biomass declining thereafter. As for the nitrate level $\left(103.78 \mathrm{mg} / \mathrm{L}\right.$ initial $\mathrm{NO}_{3}{ }^{-}$$\mathrm{N})$, it declined rapidly after $12 \mathrm{~h}$ and was nearly undetectable after $18 \mathrm{~h}$. The maximum nitrate removal rate was $15.50 \mathrm{mg} / \mathrm{L} / \mathrm{h}$, occurring between 12 and $18 \mathrm{~h}$. In addition, the variation tendency of TN concentration corresponded with that of nitrate concentration. The $\mathrm{TN}$ concentration decreased rapidly from $12 \mathrm{~h}$ onward and remained nearly constant (around $20 \mathrm{mg} / \mathrm{L}$ ) after $36 \mathrm{~h}$. Nitrite was undetectable during the entire range of the denitrifying process.

Figure 2B shows the growth and denitrification characteristics of strain DN-23 in an environment of $30 \mathrm{~g} / \mathrm{L} \mathrm{NaCl}$. The cells grew rapidly from $18 \mathrm{~h}$ onward, and remained constant after $36 \mathrm{~h}$ with an $\mathrm{OD}_{600}$ of 1.31-1.40. The nitrate showed a significant decrease from $12-24 \mathrm{~h}$ and then remained stable at $11.37 \mathrm{mg} / \mathrm{L}$, and the maximum denitrification rate was $8.26 \mathrm{mg} / \mathrm{L} / \mathrm{h}$. The TN also decreased significantly between 12 and $36 \mathrm{~h}$ and then held constant at $25.12 \mathrm{mg} / \mathrm{L}$. The results showed that the denitrification rate under stress conditions of $30 \mathrm{~g} / \mathrm{L} \mathrm{NaCl}$ was slightly inhibited compared to $0 \mathrm{~g} / \mathrm{L} \mathrm{NaCl}$. Additionally, it was noteworthy that $\mathrm{NO}_{2}{ }^{-}-\mathrm{N}$, the metabolite of $\mathrm{NO}_{3}{ }^{-}-\mathrm{N}$, was produced from $6 \mathrm{~h}$ onward, and its concentration reached a peak of $26.25 \mathrm{mg} / \mathrm{L}$ at $24 \mathrm{~h}$, while nitrite was barely detectable after $30 \mathrm{~h}$.

Figure 2C shows that the strain DN-23 was obviously inhibited under the condition of $\mathrm{NaCl} 50 \mathrm{~g} / \mathrm{L}$. The cells entered into a stable phase at $44 \mathrm{~h}$ with $\mathrm{OD}_{600} 0.56$, and the biomass cultivated in the DM with $50 \mathrm{~g} / \mathrm{L} \mathrm{NaCl}$ was significantly greater than that in $0 \mathrm{~g} / \mathrm{L}$ and $30 \mathrm{~g} / \mathrm{L} \mathrm{NaCl}$. The nitrate concentration was nearly constant after $44 \mathrm{~h}$ with an $86.37 \%$ denitrification rate. The TN concentration curve of was consistent with that of nitrate concentration. In addition, nitrite was also formed during the denitrification process, and the peak concentration reached $8.30 \mathrm{mg} / \mathrm{L}$ at $30 \mathrm{~h}$. The nitrite was converted completely after $44 \mathrm{~h}$, which was related to the variation of nitrate. Overall, the 


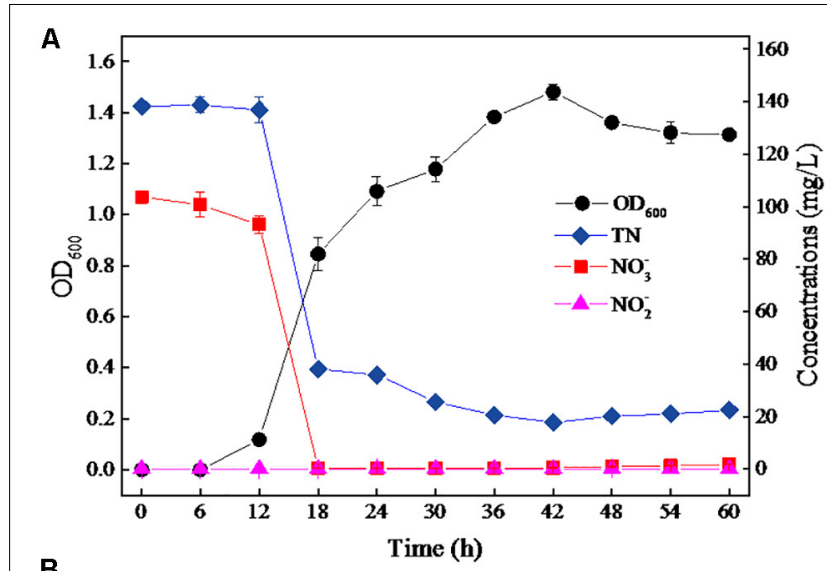

B

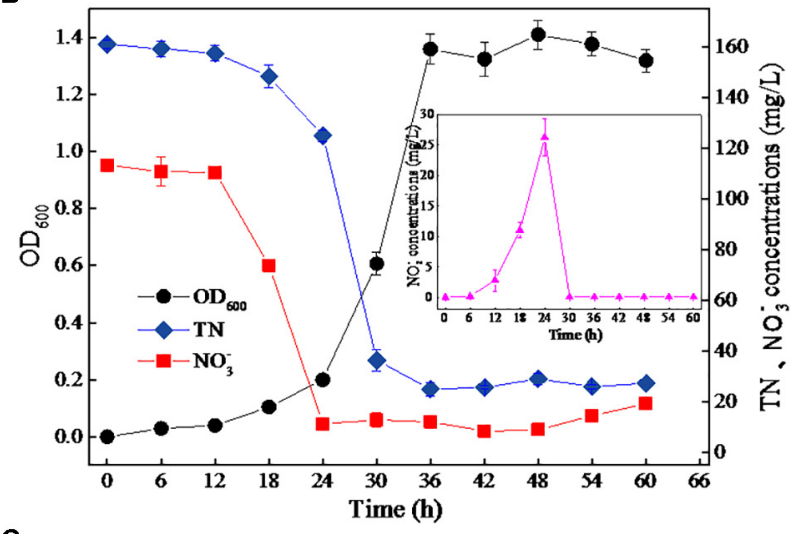

C

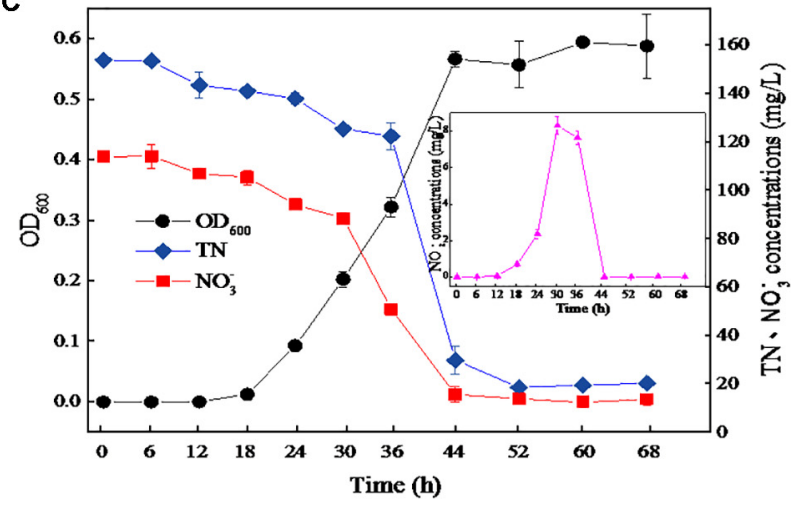

FIGURE 2 | The growth and aerobic denitrification characteristics of strain TN-10 cultivated in DM with different $\mathrm{NaCl}$ concentrations $(\mathbf{A}: 0 \mathrm{~g} / \mathrm{L} \mathrm{NaCl}$, B: $30 \mathrm{~g} / \mathrm{L} \mathrm{NaCl}, \mathbf{C}: 50 \mathrm{~g} / \mathrm{L} \mathrm{NaCl}$. Samples were collected from the DM, and

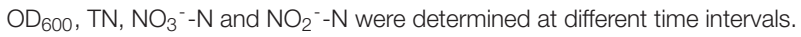
Values are means \pm SD (error bars) for three replicates.

growth and denitrification performances of strain DN-23 were significantly inhibited under high-salt conditions.

\section{Effect of $\mathrm{NaCl}$ on Antioxidative Enzyme Activity}

In the present study, we measured the activities of the main antioxidative enzymes SOD, POD, and CAT. As shown in Figure 3, the SOD activity increased slightly in the presence of $\mathrm{NaCl}(0-30 \mathrm{~g} / \mathrm{L})$ and decreased at a $\mathrm{NaCl}$ concentration of $50 \mathrm{~g} / \mathrm{L}$. Although the POD activity significantly increased with increasing $\mathrm{NaCl}$ concentration, the activity was at a very low level (0.009-0.069 U/mg protein). In addition, the activity of CAT increased considerably with the increase of $\mathrm{NaCl}$ content, and a 7.54-fold greater activity of CAT was measured under $50 \mathrm{~g} / \mathrm{L} \mathrm{NaCl}$ compared to $0 \mathrm{~g} / \mathrm{L} \mathrm{NaCl}$.

\section{Analysis of Flocculating Efficiency, Zeta Potential, and Auto-Aggregation Rate}

Figure 4 shows the flocculation properties of strain DN-23 in response to $\mathrm{NaCl}$ stress. As shown in Figure 4A, the cells quickly settled into the bottom of the centrifuge tube. Samples collected from the DM with greater $\mathrm{NaCl}$ concentrations had more flocculation in the bottom of the tube after standing. The zeta potential, flocculating efficiency, and auto-aggregation rates were then measured to quantitatively describe the aggregation performances. Zeta potential can be used to describe the electrostatic interactions between colloidal particles, which are important indicators of the stability of the colloidal system (Xu et al., 2014). In addition, the zeta potential is important for adsorption as it can indicate interactions between particles (Zadaka et al., 2010). The more negative the zeta potential, the greater the stability of particle interactions (Tong et al., 2011). Figure 4B shows the flocculating rate in the kaolin suspension and the zeta potential of the cell surface. Obviously, the zeta potentials of cells cultivated in the medium with $0 \mathrm{~g} / \mathrm{L} \mathrm{NaCl}$ were more negative than in media with 30 and $50 \mathrm{~g} / \mathrm{L} \mathrm{NaCl}$, indicating that the cells were more stable and the flocculating efficiency was lower. Meanwhile, it was noted that the flocculating efficiency increased from $27.01 \%(\mathrm{NaCl} 0 \mathrm{~g} / \mathrm{L})$ to $35.56 \%(\mathrm{NaCl} 50 \mathrm{~g} / \mathrm{L})$, which was consistent with the results of the zeta potentials. We further investigated the variation of the auto-aggregation rate over time (Figure 4C). The results showed that the strain DN-23 exhibited a greater auto-aggregation ability under high-salt stress. It seems that the auto-aggregation rate reached equilibrium after $3 \mathrm{~h}$, and the auto-aggregation rates were $44.34 \%(\mathrm{NaCl} 0 \mathrm{~g} / \mathrm{L})$, $48.62 \%(\mathrm{NaCl} 30 \mathrm{~g} / \mathrm{L})$, and $59.99 \%(\mathrm{NaCl} 50 \mathrm{~g} / \mathrm{L})$, respectively, after standing for $5 \mathrm{~h}$.

\section{EPS Characterization by 3D-EEM Fluorescence}

Figure 5 shows the 3D-EEM fluorescence of EPS extracted from strain DN-23. As shown in Figure 5, only one peak was clearly observed for all samples. Peaks are located at the excitation/emission wavelengths (Ex/Em) 285/290-295, which are all assigned to protein-like substances (Hudson et al., 2008). The fluorescence of peaks implies the presence of aromatic amino acids such as tryptophan or tyrosine. In the present study, all peak locations were close, indicating that the EPS components of all samples were similar. Analysis of the peak intensities showed that the intensity increased with the $\mathrm{NaCl}$ concentration in DM.

\section{FT-IR Spectra of EPS}

The FT-IR spectra of EPS from the three samples are shown in Figure 6. The results of FT-IR were assigned and compared 


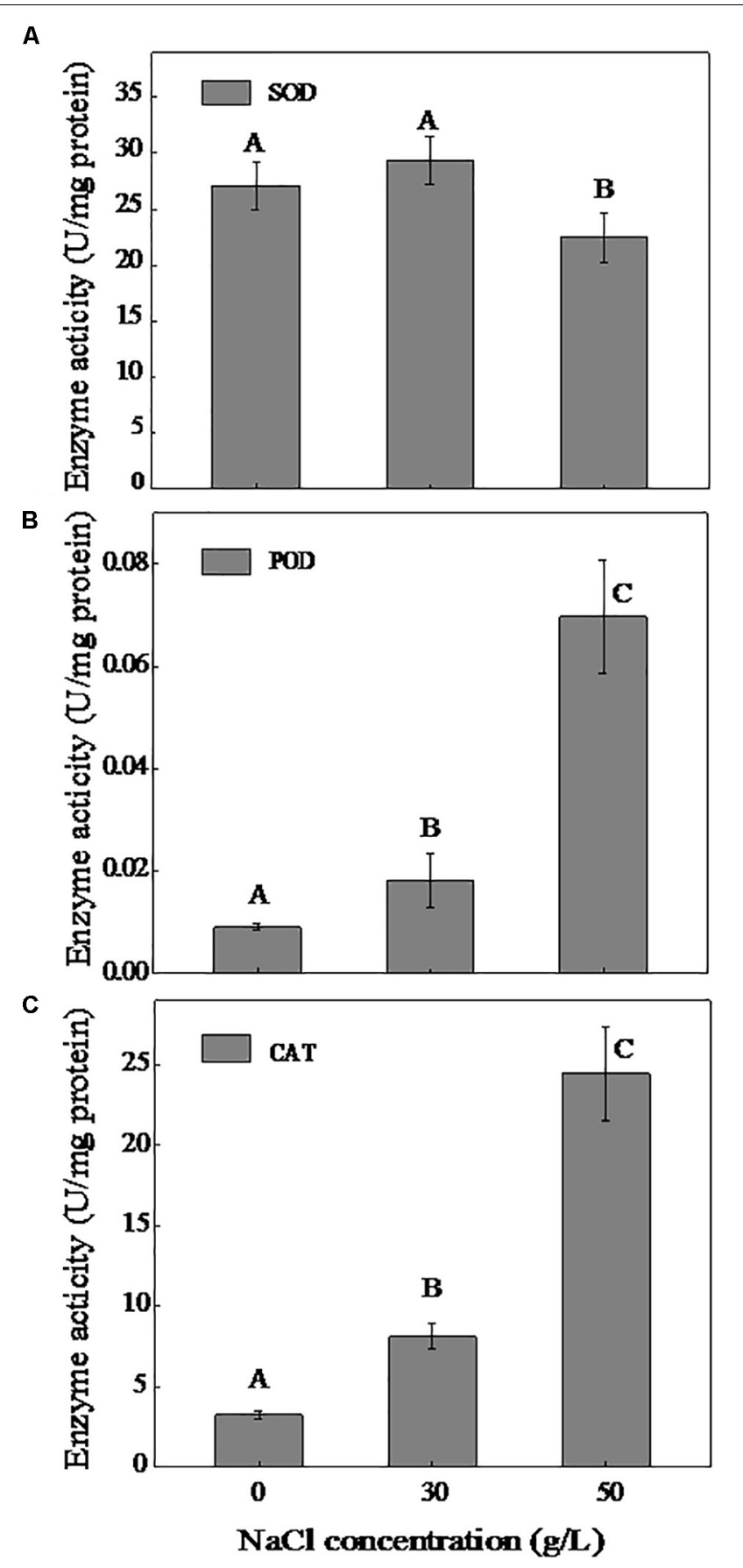

FIGURE 3 | Effect of $\mathrm{NaCl}$ on the activities of SOD (A), POD (B), and CAT (C). The cells were cultivated in the DM and collected at logarithmic metaphase (0 g/L NaCl, 24 h; 30 g/L NaCl, 30 h, and 50 g/L NaCl, 36 h). Different uppercase letters are used to indicate the significant differences of enzyme activity at $p<0.05(n=3)$. Values are means $\pm \mathrm{SD}$ (error bars) for three replicates.

according to previous literature (Liang et al., 2010). The bands at $2934-2980 \mathrm{~cm}^{-1}$ were assigned to the stretching vibration of the C-H group. The adsorption bands at $1582-1591 \mathrm{~cm}^{-1}$ were associated with the stretching vibration of $\mathrm{C}-\mathrm{N}$ in proteins.
The bands at $1455-1458 \mathrm{~cm}^{-1}$ were related to the $\mathrm{C}-\mathrm{H}$ deformation in $>\mathrm{CH}_{2}$ of proteins. The bands near $1400 \mathrm{~cm}^{-1}$ corresponded to the $\mathrm{C}=\mathrm{O}$ symmetric stretching of $\mathrm{COO}^{-1}$ in amino acids. The strong absorption bands at $1263-1265 \mathrm{~cm}^{-1}$ belonged to the deformation vibration of $\mathrm{C}=\mathrm{O}$ in nucleic acids. The bands observed at $1041-1045 \mathrm{~cm}^{-1}$ were related to the stretching vibration of polysaccharides. The bands in the region $854-926 \mathrm{~cm}^{-1}$ were attributed to the $\mathrm{C}-\mathrm{C}$ stretching vibration. Overall, the above results showed that proteins and polysaccharides were the main components of EPS. The peak locations of the three samples were similar, indicating that the $\mathrm{NaCl}$ stress had no significant effect on the EPS components, and the peaks were shifted slightly, which suggests that the contents of EPS were affected by $\mathrm{NaCl}$ stress.

\section{Effects of $\mathrm{NaCl}$ on the Components and Contents of EPS}

Based on the results of 3D-EEM and FT-IR, the main components of EPS were proteins and polysaccharides. Therefore, we measured the content of proteins and polysaccharides (Figure 7). The concentration of polysaccharides was about $55 \mathrm{mg} / \mathrm{L}$ and remained stable under different $\mathrm{NaCl}$ stresses. As for proteins, the content was $17.81 \mathrm{mg} / \mathrm{L}$ in the absence of $\mathrm{NaCl}$, and increased to $35.93 \mathrm{mg} / \mathrm{L}$ with $50 \mathrm{~g} / \mathrm{L} \mathrm{NaCl}$. In addition, we determined the compositions and contents of protein secondary structures under different $\mathrm{NaCl}$ stresses (Table 1). The results showed that $\mathrm{NaCl}$ stress had a significant influence on protein secondary structure. In the absence of $\mathrm{NaCl}$, the random coil was the predominant structure, and the relative content decreased from $35.4 \%(0 \mathrm{~g} / \mathrm{L} \mathrm{NaCl})$ to $17.7 \%(50 \mathrm{~g} / \mathrm{L} \mathrm{NaCl})$ with increasing $\mathrm{NaCl}$ content. The $\beta$-Sheets dominated the protein secondary structure in the presence of $\mathrm{NaCl}$ stress, with a significant increase in content from $15.6 \%(0 \mathrm{~g} / \mathrm{L} \mathrm{NaCl})$ to $44.9 \%(50 \mathrm{~g} / \mathrm{L} \mathrm{NaCl})$. In addition, both $\beta$-turn and $\alpha$-Helices decreased with increasing $\mathrm{NaCl}$ concentrations.

\section{DISCUSSION}

A strain with great denitrifying performance was isolated from high-salinity wastewater, and this salt-tolerant isolate was identified as Pseudomonas sp. DN-23. Culture conditions were optimized and the results suggested that the optimum carbon source was sodium acetate, $\mathrm{C} / \mathrm{N} \mathrm{12:1,} \mathrm{pH} 8$, and a temperature of $30^{\circ} \mathrm{C}$. As for the carbon source, sodium acetate is also the optimum carbon source for Vibrio diabolicus SF16, which is a halophilic nitrifying-denitrifying bacterium (Duan et al., 2015). As for the $\mathrm{C} / \mathrm{N}$, the greatest biomass and denitrification rate of strain DN-23 was obtained at C/N 12:1, similar to other heterotrophic nitrifying-aerobic denitrifying bacteria such as Pseudomonas stutzeri YG-24 (Li et al., 2015) and Agrobacterium sp. LAD9 (Yu et al., 2015). In terms of $\mathrm{pH}$, our work was consistent with the most reported nitrifying-denitrifying bacteria, such as Bacillus methylotrophicus strain L7 (Zhang et al., 2012) and Acinetobacter junii YB (Ren et al., 2014), showing better nitrifying-denitrifying abilities at a neutral or alkaline 

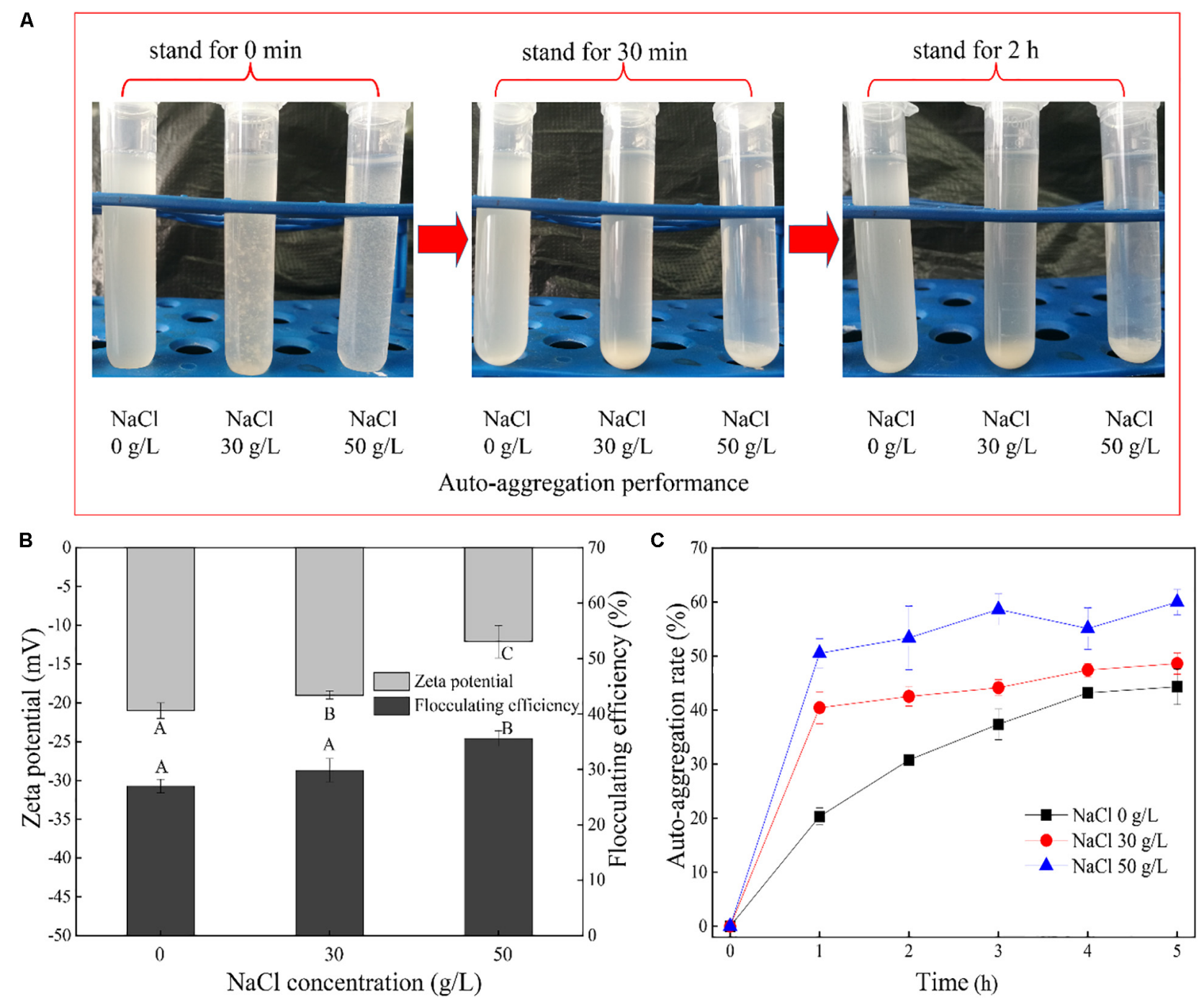

FIGURE 4 | Auto-aggregation characteristics of cells. (A): auto-aggregation performance of cells, (B): flocculating efficiency in kaolin suspension and zeta potential of the cell surface. (C): auto-aggregation rate of strain DN-23. The cells were collected at logarithmic metaphase from the DM with different NaCl concentrations. Different uppercase letters indicate the significant differences of enzyme activity at $p<0.05(n=3)$. Values are given as mean \pm SD (error bars) for three replicates.

environment. Regarding temperature, most reported nitrifyingdenitrifying are mesophiles, such as Acinetobacter junii YB (Ren et al., 2014) and Pseudomonas sp. C27 (Chen et al., 2013a), and they can barely grow at $4^{\circ} \mathrm{C}$.

The denitrification performance of DN-23 under salt stress was determined under optimized conditions (Figure 2), and the results showed that the denitrifying rate decreased with increasing $\mathrm{NaCl}$ concentration. The denitrification rate of strain DN-23 was $87.65 \%$ under $50 \mathrm{~g} / \mathrm{L} \mathrm{NaCl}$ stress, which was greater than other salt-tolerant bacteria, such as Achromobacter sp. GAD-3 (Gui et al., 2017) with an 80\% denitrification rate at $50 \mathrm{~g} / \mathrm{L} \mathrm{NaCl}$ and Bacillus methylotrophicus strain L7 (Zhang et al., 2012) with a 39\% nitrogen removal rate at $40 \mathrm{~g} / \mathrm{L} \mathrm{NaCl}$. Special attention was paid to the accumulated intermediate nitrite under salt stress, and the nitrite content was rapidly degraded in the middle of the denitrifying process, which may be ascribed to the exhaustion of nitrate and the great denitrifying performance. This was different from $A$. sp. GAD-3, whose accumulated nitrite increased to $87.4 \mathrm{mg} / \mathrm{L}$ at the end of the denitrification process under $50 \mathrm{~g} / \mathrm{L} \mathrm{NaCl}$ stress (Gui et al., 2017). Wang et al. (2017) isolated a nitrifying-denitrifying bacterium named Halomonas sp. strain B01 from the sediment of a saltern pool. After $180 \mathrm{~h}$, $99.2 \%$ inorganic nitrogen was removed by $H$. sp. strain B01, whereas lots of intermediates like nitrate and nitrite accumulated. The findings above suggest that the strain DN-23 has a faster denitrifying rate and fewer accumulated intermediates under high salt conditions, while the formation of intermediates is related to the expression of nitrifying and denitrifying genes. For instance, the gene $\mathrm{NiR}$ is responsible for the production of nitrite. It has been reported that denitrifying genes can be used as biomarkers to explore the relationship between the performance of reactors and the expression of denitrifying 

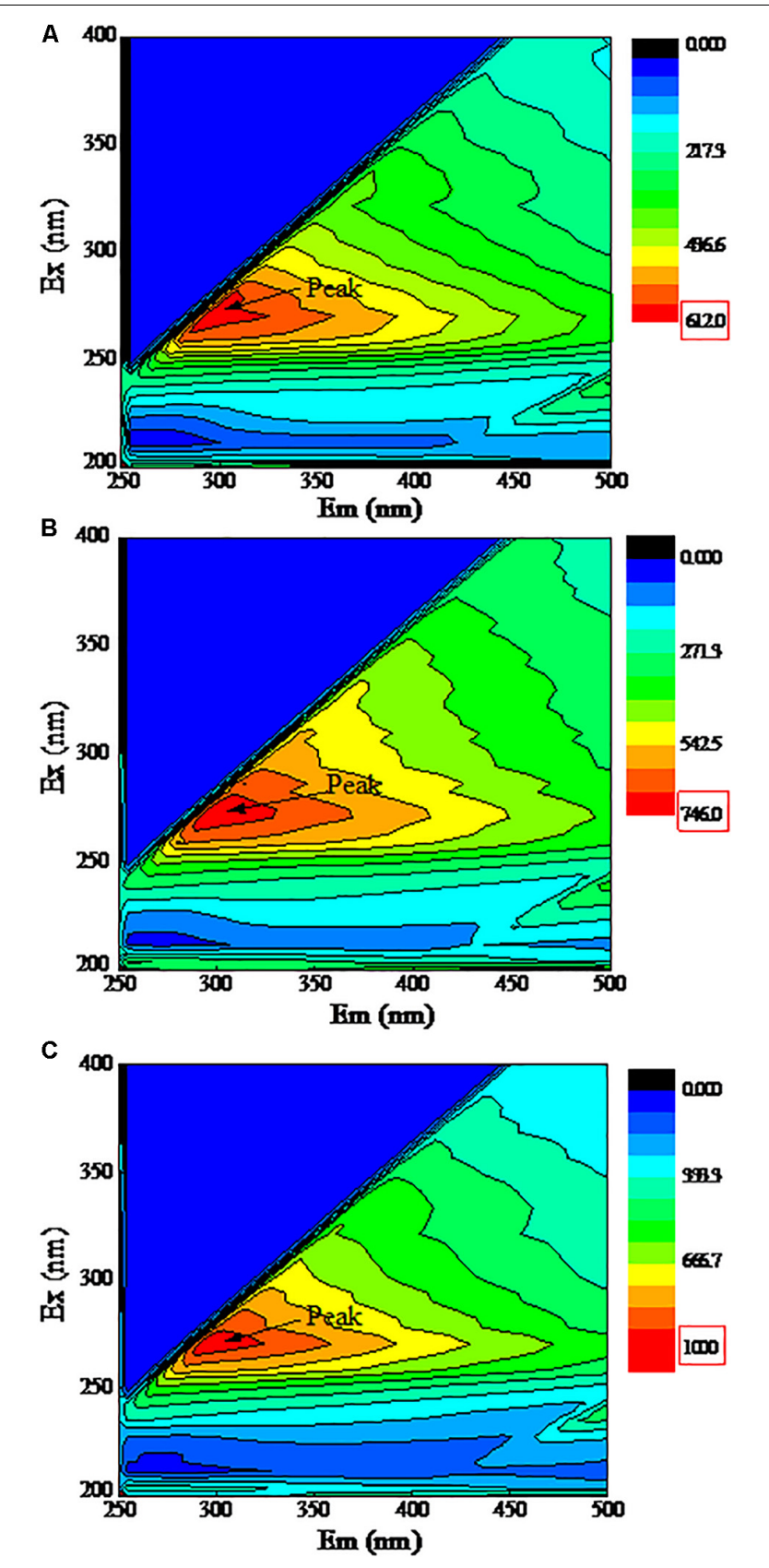

FIGURE 5 | 3D-EEM fluorescence spectra of EPS. The $X$-axis represents the emission spectra, $Y$-axis represents the excitation spectra. Cells were cultivated at $\mathrm{DM}$ with different $\mathrm{NaCl}$ stress, and the samples were collected at logarithmic metaphase. (A): $0 \mathrm{~g} / \mathrm{L} \mathrm{NaCl}$, (B): $30 \mathrm{~g} / \mathrm{L} \mathrm{NaCl,} \mathrm{(C):} 50 \mathrm{~g} / \mathrm{L} \mathrm{NaCl}$.

genes (Kuypers et al., 2018). Deng et al. (2019) also reported that salinity inhibits denitrification gene expression using multiple molecular omics, which could be adopted in our future research.

Previous research revealed that microorganisms secrete excess reactive oxygen species (ROS) under adverse conditions, and ROS destroy normal metabolism by injuring cellular components and enhancing peroxidation. Antioxidant enzymes can neutralize the toxic effects of subproducts of oxygen utilization (Zelko et al.,
2002), so we determined the activity of antioxidative enzymes (SOD, POD, CAT). The results showed that the strain DN-23 secreted more antioxidative enzymes in response to $\mathrm{NaCl}$ stress. Among them, SOD activity decreased under conditions of $50 \mathrm{~g} / \mathrm{L}$ $\mathrm{NaCl}$, possibly because high $\mathrm{NaCl}$ concentrations injure cells and inhibit antioxidative enzymes (Figure 3). Amaretti et al. (2013) also demonstrated similar phenomena. Resisting the damaging effects of $\mathrm{NaCl}$ by POD may be insufficient for maintaining a relatively low concentration. Meanwhile, CAT activity increased with $\mathrm{NaCl}$ concentration, possibly indicating that it plays a more important role in $\mathrm{NaCl}$ resistance.

In the present study, the auto-aggregation performance of DN-23 was investigated, and it was noteworthy that the strain DN-23 exhibited better auto-aggregation performance in response to $\mathrm{NaCl}$ stress (Figure 4A). In addition, quantitative analyses of flocculating efficiency and auto-aggregation rate demonstrated that the auto-aggregation rate of DN-23 under high $\mathrm{NaCl}$ stress was greater than that of other reported bacteria, such as Enterobacter sp. strain FL (Wang et al., 2018) and Escherichia coli (Eboigbodin and Biggs, 2008). To explain why $\mathrm{NaCl}$ stress increased the flocculation rate of DN-23, FT-IR and 3D-EEM were used to analyze the EPS components (Figures 5, 7 ), and the results showed that proteins and polysaccharides were the main components of EPS. Among the FT-IR results, the $\mathrm{C}=\mathrm{O}$ stretching vibration was related to $\beta$-sheets in secondary protein structures, which favored bio-flocculation (Badireddy et al., 2010). Additionally, the bands of $\mathrm{C}-\mathrm{H}$ stretching, $\mathrm{C}=\mathrm{O}$ symmetric stretching, and C-C stretching in EPS represent hydrophobic functional groups, which may contribute to the auto-aggregation of cells (Jia et al., 2017). Furthermore, the existence of Tyrosine in EPS also provided more evidence for maintaining the stability of granular structures (Zhu et al., 2012). Similar components of EPS were also found in Enterobacter sp. strain FL (Wang et al., 2018) and Bacillus megaterium TF10 (Sun et al., 2012). In addition to pure strains, biofilm activated sludge and granular sludge also have similar EPS components (Liang et al., 2010; Corsino et al., 2019). Furthermore, the fluorescent intensities of EPS increased with $\mathrm{NaCl}$ stress, indicating that $\mathrm{NaCl}$ stress affected the secretion of extracellular proteins, which may be related to the enhancement of auto-aggregation of cells cultivated in $\mathrm{DM}$ with greater $\mathrm{NaCl}$ concentrations (Figures 4, 5). It has been proven that protein-like substances play a crucial role in forming and stabilizing the structure of aggregates (Zhu et al., 2015).

Based on the results of FT-IR and EEM, the content of proteins and polysaccharides was determined (Figure 7). Although some researchers have explored the effects of $\mathrm{NaCl}$ stress on the nitrogen removal performance and EPS characteristics of activated sludge, the effects of $\mathrm{NaCl}$ stress on the EPS compositions of salt-tolerant denitrifying bacteria have rarely been reported (Campo et al., 2018; Corsino et al., 2018). In the present study, quantitative analysis was used to explore the EPS characteristics of DN-23 under $\mathrm{NaCl}$ stress. $\mathrm{NaCl}$ stress had little effect on the polysaccharide concentration of EPS, while a significant increase in protein concentration was observed during salt stress. Compared to what was described in the literature (Yan et al., 2013; Xu et al., 2014), the protein content of EPS was 


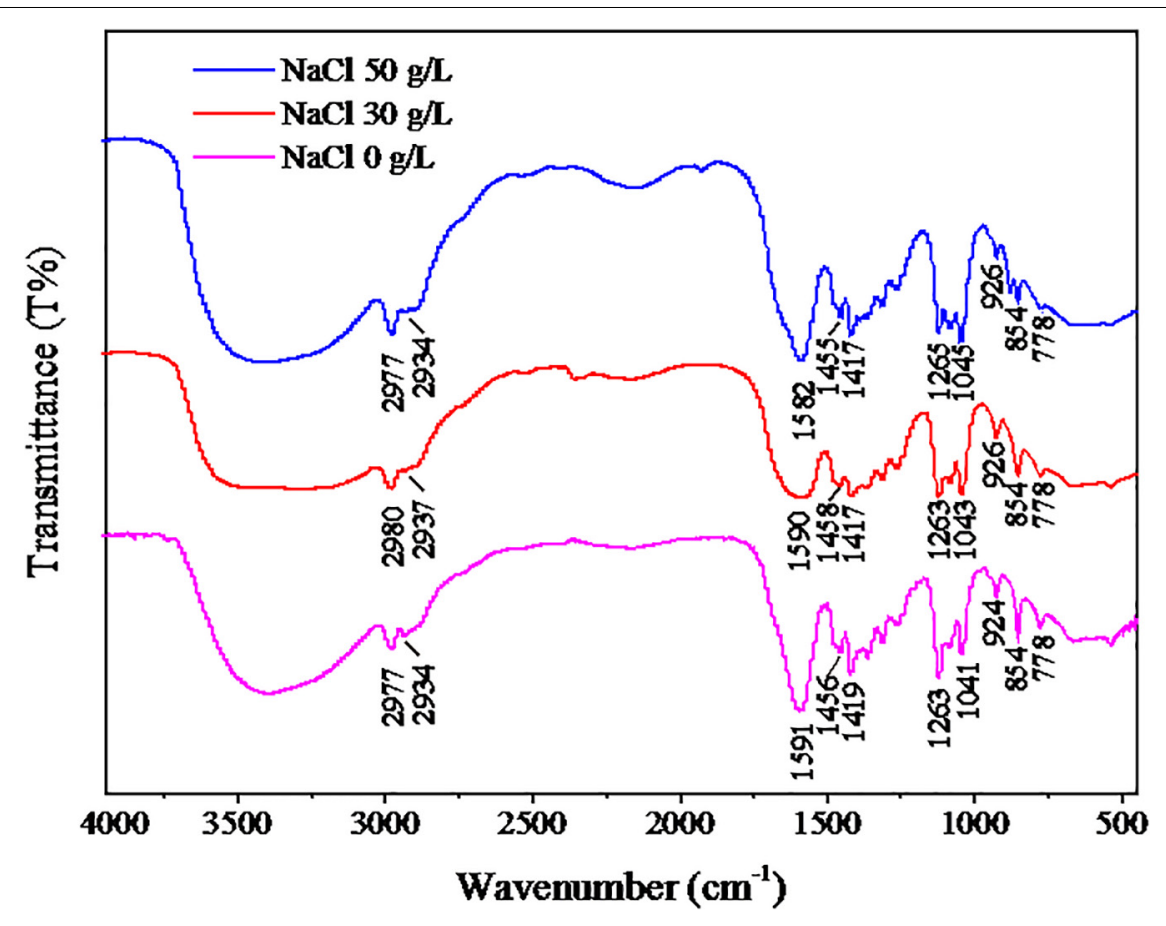

FIGURE 6 | FT-IR results of EPS. The strain was cultivated in the DM with different $\mathrm{NaCl}$ concentrations $(0,30$, or $50 \mathrm{~g} / \mathrm{L})$, and the cells were collected at logarithmic metaphase. The EPS of cells were extracted for FT-IR analysis.

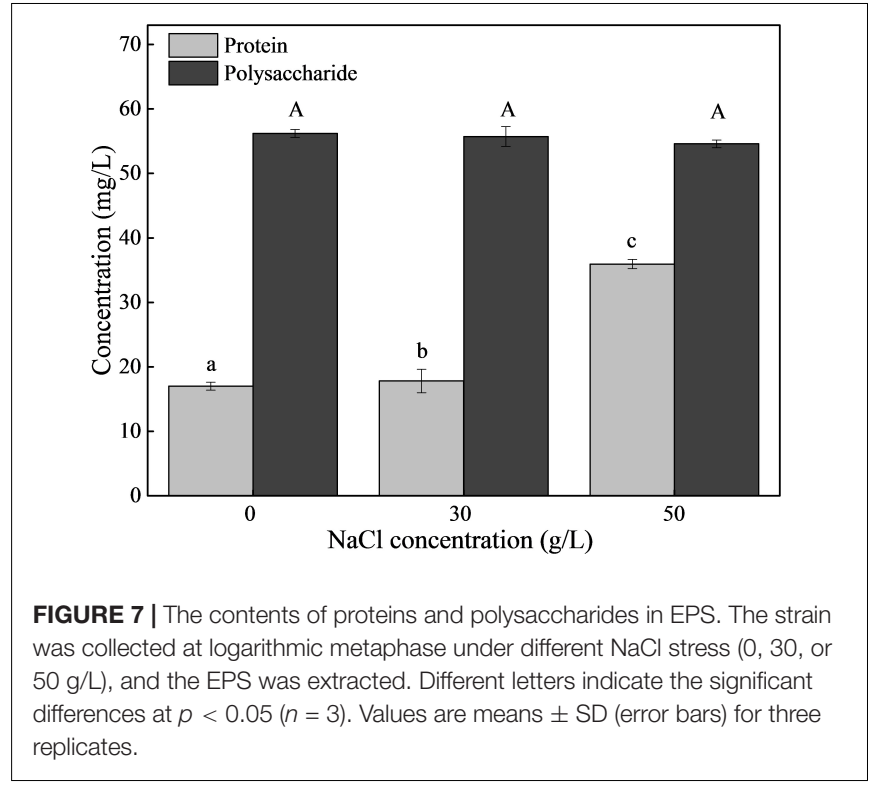

much higher, which may be due to the presence of a number of exoenzymes, as suggested by Frølund et al. (1995). Additionally, the protein content increased under $\mathrm{NaCl}$ stress, which may result from cells producing more exoenzymes when cultivated in an unfavorable environment (Adav and Lee, 2008). It is noteworthy that the variation of protein content under $\mathrm{NaCl}$ stress was in accordance with the variation of auto-aggregation ability, indicating that proteins rather than polysaccharides played
TABLE 1 | Effect of $\mathrm{NaCl}$ on protein secondary structure of EPS.

\begin{tabular}{lccc}
\hline Type (\%) & \multicolumn{3}{c}{$\mathbf{N a C l}$ content (g/L) } \\
\cline { 2 - 4 } & $\mathbf{0}$ & $\mathbf{3 0}$ & $\mathbf{5 0}$ \\
\hline$\alpha$-Helices & $23.7 \%$ & $19.4 \%$ & $16.6 \%$ \\
$\beta$-Sheets & $15.6 \%$ & $32.0 \%$ & $44.9 \%$ \\
$\beta$-turn & $25.3 \%$ & $23.1 \%$ & $20.8 \%$ \\
Random coil & $35.4 \%$ & $25.5 \%$ & $17.7 \%$ \\
\hline
\end{tabular}

a more important role in auto-aggregation ability. Similarly, Adav and Lee (Adav and Lee, 2008) have reported that the auto-aggregation of Acinetobacter calcoaceticus, cultivated in media with different phenol concentrations, was significantly stimulated by phenol. The auto-aggregation of A. calcoaceticus was positively correlated with protein content, and the secreted proteins contributed to the formation of mature granules. Wang et al. (2018) also suggested that proteins in the EPS secreted by Enterobacter sp. strain FL were important for the flocculation and aggregation of microbes.

The distribution of each protein's secondary structures was measured (Table 1), and the results showed that $\mathrm{NaCl}$ stress significantly affected the protein secondary structures of EPS. Damodaran and Kinsella reported similar results, suggesting that $\mathrm{NaCl}$ affects the hydrophobicity and hydrophilicity of proteins by altering the protein conformational structures. Zhao et al. (2011) also found that salt influences the ellipticity values of proteins near $190 \mathrm{~nm}$ according to the CD spectra. Additionally, certain protein secondary structures, such as $\beta$-Sheets and $\alpha$-Helices, 
promote bioflocculation, while random coils and antiparallel $\beta$-sheets decrease bioflocculation ability (Omoike and Chorover, 2004). In the present study, $\beta$-Sheets, which accounted for the majority of secondary structures, increased significantly with increasing $\mathrm{NaCl}$ concentrations, which may be related to the increased auto-aggregation rate in response to greater $\mathrm{NaCl}$ stress. The relative content of each protein secondary structure was different from that described in other reports. In Enterobacter sp. Strain FL, the random coil secondary structure accounted for 40\% (Wang et al., 2018). Badireddy et al. (2010) found that the random coil in EPS from activated sludge was predominant during the exponential phase. Based on the above findings, we concluded that $\mathrm{NaCl}$ stress alters the protein secondary structures of EPS and increases the auto-aggregation ability of the strain $\mathrm{TN}-10$.

In summary, a salt-tolerant denitrifying bacterium was isolated and identified, and this strain was able to remove $86.38 \%$ of nitrate without nitrite accumulation under $50 \mathrm{~g} / \mathrm{L} \mathrm{NaCl}$. Additionally, the isolate secreted more antioxidative enzymes in response to $\mathrm{NaCl}$ stress. It is worth noting that the strain exhibited greater auto-aggregation ability under $\mathrm{NaCl}$ stress. Furthermore, proteins and polysaccharides were the main components of EPS, and it was proteins rather than polysaccharides that played a more important role in auto-aggregation. The protein secondary structures of EPS were altered under $\mathrm{NaCl}$ stress, which may be related to the change in auto-aggregation.

\section{REFERENCES}

Adav, S. S., and Lee, D.-J. (2008). Single-culture aerobic granules with Acinetobacter calcoaceticus. Appl. Microbiol. Biotechnol. 78, 551-557. doi: 10.1007/s00253007-1325-x

Amaretti, A., Di Nunzio, M., Pompei, A., Raimondi, S., Rossi, M., and Bordoni, A. (2013). Antioxidant properties of potentially probiotic bacteria: in vitro and in vivo activities. Appl. Microbiol. Biotechnol. 97, 809-817. doi: 10.1007/s00253012-4241-7

APHA (1998). Standard Methods for the Examination of Water and Waste Water. Washington, DC: American Public Health Association.

Badireddy, A. R., Chellam, S., Gassman, P. L., Engelhard, M. H., Lea, A. S., and Rosso, K. M. (2010). Role of extracellular polymeric substances in bioflocculation of activated sludge microorganisms under glucose-controlled conditions. Water Res. 44, 4505-4516. doi: 10.1016/j.watres.2010.06.024

Bassin, J. P., Kleerebezem, R., Muyzer, G., Rosado, A. S., van Loosdrecht, M. C., and Dezotti, M. (2012). Effect of different salt adaptation strategies on the microbial diversity, activity, and settling of nitrifying sludge in sequencing batch reactors. Appl. Microbiol. Biotechnol. 93, 1281-1294. doi: 10.1007/s00253-011-3428-7

Bernstein, R., Belfer, S., and Freger, V. (2011). Bacterial attachment to RO membranes surface-modified by concentration-polarization-enhanced graft polymerization. Environ. Sci. Technol. 45, 5973-5980. doi: 10.1021/es1043694

Bin, Z., Baosheng, S., Min, J., Taishi, G., and Zhenghong, G. (2008). Extraction and analysis of extracellular polymeric substances in membrane fouling in submerged MBR. Desalination 227, 286-294. doi: 10.1016/j.desal.2007.06.032

Campo, R., Corsino, S. F., Torregrossa, M., and Di Bella, G. (2018). The role of extracellular polymeric substances on aerobic granulation with stepwise increase of salinity. Sep. Purif. Technol. 195, 12-20. doi: 10.1016/j.seppur.2017. 11.074

Chen, C., Ho, K. L., Liu, F. C., Ho, M., Wang, A., Ren, N., et al. (2013a). Autotrophic and heterotrophic denitrification by a newly isolated strain Pseudomonas sp. C27. Bioresour. Technol. 145, 351-356. doi: 10.1016/j.biortech.2012.12.027

Chen, Y. P., Zhang, P., Guo, J. S., Fang, F., Gao, X., and Li, C. (2013b). Functional groups characteristics of EPS in biofilm growing on different carriers. Chemosphere 92, 633-638. doi: 10.1016/j.chemosphere.2013.01.059

\section{DATA AVAILABILITY STATEMENT}

The raw data supporting the conclusions of this article will be made available by the authors, without undue reservation, to any qualified researcher.

\section{AUTHOR CONTRIBUTIONS}

DL and CW designed the study and analyzed the data. DL and XL performed the experiments. DL wrote the manuscript. CW revised the manuscript.

\section{FUNDING}

This study was funded by the National Natural Science Foundation of China (31871787).

\section{SUPPLEMENTARY MATERIAL}

The Supplementary Material for this article can be found online at: https://www.frontiersin.org/articles/10.3389/fmicb. 2020.00335/full\#supplementary-material

Clesceri, L., Greenberg, A. S., and Eaton, D. L. (2005). Standard Methods for the Examinations of Water and Wastewater. Washington, DC: American Journal of Public Health and the Nation's Health.

Corsino, S. F., Campo, R., Bella, G. D., Torregrossa, M., and Viviani, G. (2015). Cultivation of granular sludge with hypersaline oily wastewater. Int. Biodeterior. Biodegradation 105, 192-202. doi: 10.1016/j.ibiod.2015.09.009

Corsino, S. F., Capodici, M., Di Pippo, F., Tandoi, V., and Torregrossa, M. (2019). Comparison between kinetics of autochthonous marine bacteria in activated sludge and granular sludge systems at different salinity and SRTs. Water Res. 148, 425-437. doi: 10.1016/j.watres.2018.10.086

Corsino, S. F., Capodici, M., Torregrossa, M., and Viviani, G. (2018). A comprehensive comparison between halophilic granular and flocculent sludge in withstanding short and long-term salinity fluctuations. J. Water Process Eng. 22, 265-275. doi: 10.1016/j.jwpe.2018.02.013

Deng, Y., Ruan, Y., Ma, B., Timmons, M. B., Lu, H., Xu, X., et al. (2019). Multiomics analysis reveals niche and fitness differences in typical denitrification microbial aggregations. Environ. Int. 132:105085. doi: 10.1016/j.envint.2019. 105085

Duan, J., Fang, H., Bing, S., Chen, J., and Lin, J. (2015). Characterization of a halophilic heterotrophic nitrification-aerobic denitrification bacterium and its application on treatment of saline wastewater. Bioresour. Technol. 179, 421-428. doi: 10.1016/j.biortech.2014.12.057

Eboigbodin, K. E., and Biggs, C. A. (2008). Characterization of the extracellular polymeric substances produced by Escherichia coli using infrared spectroscopic, proteomic, and aggregation studies. Biomacromolecules 9, 686-695. doi: 10. $1021 / \mathrm{bm} 701043 \mathrm{c}$

Eom, H., Kim, J., Kim, S., and Lee, S.-S. (2018). Treatment of saline wastewater containing a high concentration of salt using marine bacteria and aerobic granule sludge. J. Environ. Eng. 144:04018026. doi: 10.1061/(asce)ee.1943-7870. 0001354

Frølund, B., Griebe, T., and Nielsen, P. H. (1995). Enzymatic activity in the activated-sludge floc matrix. Appl. Microbiol. Biotechnol. 43, 755-761. doi: 10. 1007/BF00164784

Ge, Q., Yue, X., and Wang, G. (2015). Simultaneous heterotrophic nitrification and aerobic denitrification at high initial phenol concentration by isolated 
bacterium Diaphorobacter sp. PD-7. Chin. J. Chem. Eng. 23, 835-841. doi: 10.1016/j.cjche.2015.02.001

Gui, M., Chen, Q., and Ni, J. (2017). Effect of $\mathrm{NaCl}$ on aerobic denitrification by strain Achromobacter sp. GAD-3. Appl. Microbiol. Biotechnol. 101, 5139-5147.

Gupta, A., and Thakur, I. S. (2016). Study of optimization of wastewater contaminant removal along with extracellular polymeric substances (EPS) production by a thermotolerant Bacillus sp. ISTVK1 isolated from heat shocked sewage sludge. Bioresour. Technol. 213, 21-30. doi: 10.1016/j.biortech.2016.02. 040

Huang, X., Cheng, W., and Hu, Y. (2005). Screening of flocculant-producing strains by NTG mutagenesis. J. Environ. Sci. (China) 17, 494-498. doi: 10.3321/ j.issn:1001-0742.2005.03.032

Hudson, N., Baker, A., Ward, D., Reynolds, D. M., Brunsdon, C., Carliell-Marquet, C., et al. (2008). Can fluorescence spectrometry be used as a surrogate for the biochemical oxygen demand (BOD) test in water quality assessment? An example from South West England. Sci. Total Environ. 391, 149-158. doi: 10.1016/j.scitotenv.2007.10.054

Jia, C., Li, X., Allinson, G., Liu, C., and Gong, Z. (2016). Composition and morphology characterization of exopolymeric substances produced by the PAH-degrading fungus of Mucor mucedo. Environ. Sci. Pollut. Res. Int. 23, 8421-8430. doi: 10.1007/s11356-015-5986-1

Jia, F., Yang, Q., Liu, X., Li, X., Li, B., Zhang, L., et al. (2017). Stratification of extracellular polymeric substances (EPS) for aggregated anammox microorganisms. Environ. Sci. Technol. 51, 3260-3268. doi: 10.1021/acs.est. 6b05761

Kuypers, M. M. M., Marchant, H. K., and Kartal, B. (2018). The microbial nitrogencycling network. Nat. Rev. Microbiol. 16, 263-276. doi: 10.1038/nrmicro.2018.9

Li, A., Zhou, C., Liu, Z., Xu, X., Zhou, Y., Zhou, D., et al. (2018). Direct solid-state evidence of $\mathrm{H}_{2}$-induced partial $\mathrm{U}(\mathrm{VI})$ reduction concomitant with adsorption by extracellular polymeric substances (EPS). Biotechnol. Bioeng. 115, 16851693. doi: 10.1002/bit.26592

Li, C., Yang, J., Wang, X., Wang, E., Li, B., He, R., et al. (2015). Removal of nitrogen by heterotrophic nitrification-aerobic denitrification of a phosphate accumulating bacterium Pseudomonas stutzeri YG-24. Bioresour. Technol. 182, 18-25. doi: 10.1016/j.biortech.2015.01.100

Liang, Z., Li, W., Yang, S., and Du, P. (2010). Extraction and structural characteristics of extracellular polymeric substances (EPS), pellets in autotrophic nitrifying biofilm and activated sludge. Chemosphere 81, 626-632. doi: $10.1016 /$ j.chemosphere.2010.03.043

Omoike, A., and Chorover, J. (2004). Spectroscopic study of extracellular polymeric substances from Bacillus subtilis: aqueous chemistry and adsorption effects. Biomacromolecules 5, 1219-1230. doi: 10.1021/bm034461z

Perez-Iratxeta, C., and Andrade-Navarro, M. A. (2008). K2D2: estimation of protein secondary structure from circular dichroism spectra. BMC Struct. Biol. 8:25. doi: $10.1186 / 1472-6807-8-25$

Raman, C. D., and Kanmani, S. (2016). Textile dye degradation using nano zero valent iron: a review. J. Environ. Manage. 177, 341-355. doi: 10.1016/j.jenvman. 2016.04.034

Raunkjær, K., Hvitved-Jacobsen, T., and Nielsen, P. H. (1994). Measurement of pools of protein, carbohydrate and lipid in domestic wastewater. Water Res. 28, 251-262. doi: 10.1016/0043-1354(94)90261-5

Ren, Y. X., Yang, L., and Liang, X. (2014). The characteristics of a novel heterotrophic nitrifying and aerobic denitrifying bacterium, Acinetobacter junii YB. Bioresour. Technol. 171, 1-9. doi: 10.1016/j.biortech.2014.08.058

Sheng, G. P., and Yu, H. Q. (2006). Chemical-equilibrium-based model for describing the strength of sludge: taking hydrogen-producing sludge as an example. Environ. Sci. Technol. 40, 1280-1285. doi: 10.1021/es0518528

Sreerama, N., and Woody, R. W. (2000). Estimation of protein secondary structure from circular dichroism spectra: comparison of CONTIN, SELCON, and CDSSTR methods with an expanded reference set. Anal. Biochem. 287, 252-260. doi: 10.1006/abio.2000.4880

Sun, M., Li, W. W., Mu, Z. X., Wang, H. L., Yu, H. Q., Li, Y. Y., et al. (2012). Selection of effective methods for extracting extracellular polymeric substances (EPSs) from Bacillus megaterium TF10. Sep. Purif. Technol. 95, 216-221. doi: 10.1016/j.seppur.2012.05.010

Tong, X. J., Li, J.-Y., Yuan, J.-H., and Xu, R.-K. (2011). Adsorption of $\mathrm{Cu}(\mathrm{II})$ by biochars generated from three crop straws. Chem. Eng. J. 172, 828-834. doi: 10.1016/j.cej.2011.06.069
Tourney, J., Ngwenya, B. T., Mosselmans, J. F., and Magennis, M. (2009). Physical and chemical effects of extracellular polymers (EPS) on $\mathrm{Zn}$ adsorption to Bacillus licheniformis S-86. J. Colloid Interface Sci. 337, 381-389. doi: 10.1016/j. jcis.2009.05.067

Wang, T., Li, J., Zhang, L. H., Yu, Y., and Zhu, Y. M. (2017). Simultaneous heterotrophic nitrification and aerobic denitrification at high concentrations of $\mathrm{NaCl}$ and ammonia nitrogen by Halomonas bacteria. Water Sci. Technol. 76, 386-395. doi: 10.2166/wst.2017.214

Wang, X., An, Q., Zhao, B., Guo, J. S., Huang, Y. S., and Tian, M. (2018). Autoaggregation properties of a novel aerobic denitrifier Enterobacter sp. strain FL. Appl. Microbiol. Biotechnol. 102, 2019-2030. doi: 10.1007/s00253-017-8720-8

Wang, Z., Zhang, X. X., Lu, X., Liu, B., Li, Y., Long, C., et al. (2014). Abundance and diversity of bacterial nitrifiers and denitrifiers and their functional genes in tannery wastewater treatment plants revealed by high-throughput sequencing. PLoS One 9:e113603. doi: 10.1371/journal.pone.0113603

Xu, Y., Hou, M., Ruan, J., Qu, M., Sun, H., Xu, J., et al. (2014). Effect of magnetic field on surface properties of Bacillus cereus $\mathrm{CrA}$ and its extracellular polymeric substances (EPS). J. Adhes. Sci. Technol. 28, 2196-2208. doi: 10.1080/01694243. 2014.951303

Yan, L., Ai-Min, L., Juan, X., Wen-Wei, L., and Han-Qing, Y. (2013). Formation of soluble microbial products (SMP) by activated sludge at various salinities. Biodegradation 24, 69-78. doi: 10.1007/s10532-012-9558-5

Yu, M., Liao, R., Zhang, X. X., Bo, L., Yan, L., Bing, W., et al. (2015). Metagenomic insights into salinity effect on diversity and abundance of denitrifying bacteria and genes in an expanded granular sludge bed reactor treating high-nitrate wastewater. Chem. Eng. J. 277, 116-123. doi: 10.1016/j.cej.2015.04.125

Zadaka, D., Radian, A., and Mishael, Y. G. (2010). Applying zeta potential measurements to characterize the adsorption on montmorillonite of organic cations as monomers, micelles, or polymers. J. Colloid Interface Sci. 352, 171-177. doi: 10.1016/j.jcis.2010.08.010

Zelko, I. N., Mariani, T. J., and Folz, R. J. (2002). Superoxide dismutase multigene family: a comparison of the CuZn-SOD (SOD1), Mn-SOD (SOD2), and ECSOD (SOD3) gene structures, evolution, and expression. Free Radic. Biol. Med. 33, 337-349. doi: 10.1016/s0891-5849(02)00905-x

Zhang, P., Fang, F., Chen, Y.-P., Shen, Y., Zhang, W., Yang, J.-X., et al. (2014). Composition of EPS fractions from suspended sludge and biofilm and their roles in microbial cell aggregation. Chemosphere 117, 59-65. doi: 10.1016/j. chemosphere.2014.05.070

Zhang, Q. L., Liu, Y., Ai, G. M., Miao, L. L., Zheng, H. Y., and Liu, Z. P. (2012). The characteristics of a novel heterotrophic nitrification-aerobic denitrification bacterium, Bacillus methylotrophicus strain L7. Bioresour. Technol. 108, 35-44. doi: 10.1016/j.biortech.2011.12.139

Zhao, X., Ao, Q., Du, F., and Zhu, Q. (2011). Conformation analysis of soybean protein in reverse micelles by circular dichroism spectroscopy. Food Anal. Methods 4, 268-275. doi: 10.1007/s12161-010-9162-4

Zheng, M., He, D., Ma, T., Chen, Q., Liu, S., Ahmad, M., et al. (2014). Reducing $\mathrm{NO}$ and $\mathrm{N}(2) \mathrm{O}$ emission during aerobic denitrification by newly isolated Pseudomonas stutzeri PCN-1. Bioresour. Technol. 162, 80-88. doi: 10.1016/j. biortech.2014.03.125

Zhu, L., Qi, H.-Y., Kong, Y., Yu, Y.-W., and Xu, X.-Y. (2012). Component analysis of extracellular polymeric substances (EPS) during aerobic sludge granulation using FTIR and 3D-EEM technologies. Bioresour. Technol. 124, 455-459. doi: 10.1016/j.biortech.2012.08.059

Zhu, L., Zhou, J., Lv, M., Yu, H., Zhao, H., and Xu, X. (2015). Specific component comparison of extracellular polymeric substances (EPS) in flocs and granular sludge using EEM and SDS-PAGE. Chemosphere 121, 26-32. doi: 10.1016/j. chemosphere.2014.10.053

Conflict of Interest: The authors declare that the research was conducted in the absence of any commercial or financial relationships that could be construed as a potential conflict of interest.

Copyright (c) $2020 \mathrm{Li}$, Liang and $\mathrm{Wu}$. This is an open-access article distributed under the terms of the Creative Commons Attribution License (CC BY). The use, distribution or reproduction in other forums is permitted, provided the original author(s) and the copyright owner(s) are credited and that the original publication in this journal is cited, in accordance with accepted academic practice. No use, distribution or reproduction is permitted which does not comply with these terms. 